\title{
Combined school/ public libraries in Israel at the high school level: some results of an exploratory field study
}

\section{MiRIAM HiRam}

\author{
Department of Libraries, Ministry of Education and Culture, \\ Jerusalem
}

\author{
MOSHE YITZHAKI \\ Department of Information and Library Studies, Bar-llan \\ University, Ranat-Gan Israel, 52900, e-mail: \\ yitzhm@mail.biu.ac.il
}

\begin{abstract}
A B S T RACT
The issue of combined school-public libranies has long concemed researchers and practitioness in the field and is well documented in literature. A literature survey reveals opinion articles as well as empirical field studies, especially in the US, Canada, UK, Australia and Germany, which attempt to determine the advantages and disadvantages of this model, and possible factors asscxiated with its success in practice. Despite the importance of the topic and its potential of budget savings and greater efficiency in use of resources, no large-scale empirical study of the extent and performance of combined school-public libraries in tsrael has been condivted.

The study aimed to empirically investigate the combined school-public libraries on the high school level existing in israel. The main research tools were three different witten closed questionnaires sent to the school librarian, school principal and one of the school teachers. In 1996 questionnaires were mailed to all 65 schools known to have some type of combination libraries: 26 had a combined school-public library, while in the remaining 39 schools the library was a branch of a regional or municipal public library. Questionnaires were also mailed to 40 rando'nly-chosen schools, having a 'regular' (i.e. not combined) library, to serve as a control group. Response rate was about $50 \%$ and the final sample included 51 libraries: 18-combined, 11 - 'branches', and 22- 'regular' ones.
\end{abstract}

Main findings were: the number of combined libraries has risen constantly over the decades which seems to be an interesting trend, especially in view of the recent decline reported in the US and Canada. Regarding space and seats the situation in the regional libraries was much better than in the urban ones. Concerning opening hours the urban combined libraries were open longer than the regional combined ones and the control group. The combined libraries, mainly the urban ones, were open for more atternoon hours, all of them were open during school vacations, and they had a higher average

Education for All: Culture, Reading and Intormation, IASL, 1998 
number of weekly librarian hours per school. Regional combined libraries had a much larger number of books per student and periodicals and computers per library than the urban combined ones and the control group. The mean number of users of the reading-room was about the same (usually low) in all types of libraries in afternoon hours, but differed considerably in the mornings, probably due to different teaching methods.

About half the librarians, the school principals and the teachers in the combined libraries rated their combined library as 'very successiul', while the rest rated it as only 'partially successful', or expressed dissatisfaction, pointing out serious problems. Regional librarians were much more satisfied with the combined model, compared to their urban colleagues. Findings indicated that the combined model is more likely to succeed in a regional library. in a rural setting, than in an urban one.

\section{Background}

The issue of combined school-public libraries has long concerned researchers and practitioners in the field and is well documented in literature. A literature survey reveals dozens of opinion articles as well as research papers reporting empirical field studies, especially in the US, Canada, UK, Australia and Scandinavian countries, which attempt to determine the advantages and disadvantages of this model, and possible factors associated with its success in practice.

Summarizing the literature from the 1940's, and enumerating the many reasons against the combined model, White (1963) concluded that most writers opposed the combined model, which did not solve the problem of duplicated collections. She claimed that locating the combined library on school grounds was unfavorable to many adult users. A follow-up study by Unger (1975) revealed that 25 of the combined libraries eventually' separated, while others reported worse service to adults. Haycock (1973, 1990) pointed out some major considerations in the planning of a combined library, but preferred cooperation between both types of libraries than combining them into one unit. He pointed out the unique tasks and functions of each type, calling for careful steps when considering the combination of both types into one functioning library. Woolard (1980) strongly denied the claim that the combined model saves money, arguing that a successful and efficient combination requires heavy rinancial investment and concluded that the combined model better suits small communities with populations of 5000 to 10000 . Indeed, Aaron and Smith (1977) failed to find clear evidence of saved resources in the seven combined North American libraries they studied and claimed that lack of financial resources was a main cause of the failure of many combined libraries. The Canadian and Australian experience was discussed in a collection of papers edited by Amey (1987) and later, the whole issue was discussed at length again by Aaron (1993) who reviewed about 50 articles on the topic.

Despite the importance of the topic and its potential of budget savings and greater efficiency in use of resources, except for very limited treatment in a few seminar papers, no large-scale empirical study of the extent and performance of combined school-public libraries in Israel has been conducted. 


\section{Purpose of the study}

The study aimed to empirically investigate the combined school-public libraries on the high school level existing in Israel, or more specifically:

To establish the scope of this phenomenon.

To discover the specific problems faced by these libraries.

To determine the unique features distinguishing them from other high school libraries.

To determine the level of service they provide to their users, compared to regular school libraries.

\section{Methodology}

The main research tools were three different written closed questionnaires sent to the school librarian, school principal and one of the school teachers. The librarian's questionnaire was the most detailed one, asking about various aspects of the library's daily operation, while the other two questionnaires were much shorter, focusing mainly on school's contribution to the library, its use and its success, as viewed by principal and teachers working at that school. In 1996 questionnaires were mailed to all 65 schoo's known to have some type of combination libraries: 26 had a combined school-public library, while in the remaining 39 schools the library was a branch of a regional or municipal public library. Questionnaires were also mailed to 40 randomly-chosen schools. having a 'regular' (i.e. not combined) library, to serve as a control group. Response rate was about $50 \%$ and the final sample included 51 libraries: 18- combined, 11-. 'branches', and 22- 'regular' ones. Eight of the libraries were visited personally and in-depth interviews were conducted with librarians and principais, focusing mainly on advantages and disadvantages of the combined type and its typical problems.

\section{Findings}

The number of combined libraries has risen constantly over the decades: while only two regional ones existed in 1965, eight more were established in the following period, mostly between 1970 and 1990. In the urban sector the process started later, probably spurred by the successiul experience in the rural sector (i.e. regional libraries) and all but one of the libraries were established from 1980 on, half of them recently in the 1990's. This seems to be an interesting trend, especially in view of the recent decline reported in the US and Canada.

Table 1 shows that while main combined libraries were divided almost evenly between regional councils on one hand and local councils and townships on the other, most branches belonged to regional councils, unlike most of the control group. On the average, branches had much less students than the other two groups, close to $57 \%$ only. 


\begin{tabular}{|c|c|c|c|c|}
\hline $\begin{array}{l}\text { Distributic } \\
\text { (in \%) }\end{array}$ & of Libra & Accorc & Type of Lo & overnment \\
\hline $\begin{array}{l}\text { Geographical Location } \\
\text { of School }\end{array}$ & $\begin{array}{l}\text { Combined } \\
\text { Libraries }\end{array}$ & Branches & Control Group & Total \\
\hline Regional Council & 55.5 & 81.8 & 31.8 & 51.0 \\
\hline $\begin{array}{l}\text { Town, City or Local } \\
\text { Council }\end{array}$ & 44.4 & 18.2 & 68.2 & 49.0 \\
\hline Total & $100.0 \%$ & $100.0 \%$ & $100.0 \%$ & $100.0 \%$ \\
\hline$N$ & 18 & 11 & 22 & 51 \\
\hline $\begin{array}{l}\text { Mean No. of Students } \\
\text { per Library }\end{array}$ & 979 & 537 & 902 & 850 \\
\hline
\end{tabular}

\section{Location:}

Table 2 presents the distribution of the sampled libraries according to their location on or near school grounds. Professional literature puts a strong emphasis on the importance of choosing the right location for the combined library, a factor contributing significantly to its success. There is a consensus that the library should be located in a central place, easily accessible to school students and to the public.

\begin{tabular}{|c|c|c|c|c|}
\hline Location of library & $\begin{array}{l}\text { Combined } \\
\text { Libraries }\end{array}$ & $\begin{array}{l}\text { Combined } \\
\text { Branches }\end{array}$ & $\begin{array}{l}\text { Control } \\
\text { Group }\end{array}$ & Total \\
\hline School's Ground Floor & 22.2 & 0 & 22.7 & 17.6 \\
\hline Other Floor & 22.2 & 27.3 & 31.8 & 27.5 \\
\hline Air-Raid shelter & 5.5 & 9.1 & 22.7 & 13.7 \\
\hline $\begin{array}{l}\text { Separate Building on School } \\
\text { Grounds }\end{array}$ & 38.9 & 63.6 & 22.7 & 37.3 \\
\hline $\begin{array}{l}\text { Separate Building outside } \\
\text { School Grounds }\end{array}$ & 11.1 & 0 & 0 & 3.9 \\
\hline Total & $100.0 \%$ & $100.0 \%$ & $100.0 \%$ & $100.0 \%$ \\
\hline$N$ & 18 & 11 & 22 & 51 \\
\hline
\end{tabular}

Table 2 figures show that almost half $(48 \%)$ of the 29 combined libraries (main ones and branches) were located in separate buildings on school grounds, a preferable location for the combined model. About $14 \%$ were located on the school's first floor, a second-best location, less convenient for the general public, and about $7 \%$ were located outside the school area, which is less convenient for the school students. In contrast, more than half of the libraries in the control group, which serve school students only, were located on the iirst $(23 \%)$ or other floor $(32 \%)$, or in air-raid shelters $(23 \%)$, always with in the school building, and the rest $(23 \%)$ in a separate building on school grounds. Concerning the two latter locations, totaling $46 \%$, it is doubtful whether they are consistent with one of the 
principles of the philosophy of the library media center, requiring its location at the heart of the school.

Table 3 shows that regarding space, the regional combined libraries (typical to rural areas), whether main or branches, were much better off than all other groups, combined or not: while the mean area of the former was between 322 and $396 \mathrm{~m}^{2}$ (50 to 60 percent beyond the recommended standard) the mean for the other groups was considerably lower, 25 to 50 percent below the minimal recommended standard based on school size.

\section{Table 3: Actual Space of Libraries Compared to Recommended Standard}

\begin{tabular}{lclllll}
\hline Library Type & $N$ & $\begin{array}{l}\text { Average } \\
\text { Library } \\
\text { Space } \\
\text { (in } \mathrm{m}^{2} \text { ) }\end{array}$ & $\begin{array}{l}\text { Recomm. } \\
\text { Space } \\
\text { (in } \mathrm{m}^{2} \text { ) }\end{array}$ & $\begin{array}{l}\text { \% of } \\
\text { Deviation } \\
\text { from } \\
\text { Recomm. }\end{array}$ & $\begin{array}{l}\text { No. } \\
\text { of Lib. } \\
\text { Exceeding } \\
\text { Recomm. }\end{array}$ & $\begin{array}{l}\% \\
\text { of Lib. }\end{array}$ \\
$\begin{array}{l}\text { Stand. } \\
\text { Recomm. }\end{array}$ & $\begin{array}{l}\text { Recond. } \\
\text { Stand. }\end{array}$ \\
\hline $\begin{array}{l}\text { Combined } \\
\text { Regional }\end{array}$ & 10 & 396 & 250 & 58.3 & 9 & 90.0 \\
$\begin{array}{l}\text { Combined } \\
\text { Local/Town }\end{array}$ & 8 & 215 & 300 & -28.4 & 2 & 25.0 \\
$\begin{array}{l}\text { Combined } \\
\text { Branch } \\
\text { (regional) }\end{array}$ & 9 & 322 & 217 & 48.7 & 7 & 77.8 \\
$\begin{array}{l}\text { Combined } \\
\text { Branch } \\
\text { (local/town) }\end{array}$ & 2 & 72 & 150 & -52.0 & 0 & 0 \\
$\begin{array}{l}\text { Control Group } \\
\text { (regional) }\end{array}$ & 7 & 199 & 264 & -24.9 & 3 & 42.9 \\
$\begin{array}{l}\text { Control Group } \\
\text { (local/town) }\end{array}$ & 15 & 183 & 257 & -28.6 & 5 & 33.3 \\
\hline
\end{tabular}

Heading the list were the regional combined libraries, of which $80 \%-90 \%$ exceeded the recommended standard. This group was followed by the control group and the combined libraries located in towns or in local councils, which on the average were below the recommended standard (deviation of $25 \%-29 \%$ ) with only $25 \%$ to $43 \%$ of them exceeding it. Worst off were the combined branches located in towns or in local councils, which deviated by $-52 \%$ from the standard, with no library reaching it. Similarly, the regional libraries had more seats than the urban ones or the control group.

The possible explanation for these differences are that regional councils, having greater resources, probably invest and allocate more funds to their school libraries, especially if they are combined, while political leaders heading towns (or local councils) invest much less in their libraries, whether combined or not, probably due to lack of funds resulting from a different scale of priorities. 
Table 4: Average Number of Books per Student in Various Types of Libraries

\begin{tabular}{|c|c|c|c|c|c|}
\hline Library Type & $N$ & $\begin{array}{l}\text { Average No. } \\
\text { of Books per } \\
\text { Library }\end{array}$ & $\begin{array}{l}\text { Actual No. } \\
\text { of Books } \\
\text { per Student }\end{array}$ & $\begin{array}{l}\text { Recomm. } \\
\text { No. of Books } \\
\text { per Student }\end{array}$ & $\begin{array}{l}\text { Ratio of } \\
\text { Actual No. to } \\
\text { Recomm. }\end{array}$ \\
\hline $\begin{array}{l}\text { Combined } \\
\text { Regional }\end{array}$ & 10 & 34477 & 47.4 & 10 & 4.74 \\
\hline $\begin{array}{l}\text { Combined } \\
\text { Local/Town }\end{array}$ & 8 & 15405 & 13.5 & 10 & 1.35 \\
\hline $\begin{array}{l}\text { Combined } \\
\text { Branch (regional) }\end{array}$ & 9 & 20786 & 34.3 & 10 & 3.43 \\
\hline $\begin{array}{l}\text { Combined } \\
\text { Branch } \\
\text { (local/town) }\end{array}$ & 2 & 777 & 1.7 & 10 & 0.17 \\
\hline $\begin{array}{l}\text { Control Group } \\
\text { (regional) }\end{array}$ & 7 & 12739 & 17.7 & 10 & 1.77 \\
\hline $\begin{array}{l}\text { Control Group } \\
\text { (local/town) }\end{array}$ & 15 & 10301 & 10.4 & 10 & 1.04 \\
\hline
\end{tabular}

Table 4 indicates again that those libraries located in and funded by regional councils were better off also regarding book collection size. In each of the three main head-groups (i.e. combined main libraries, combined branches and control group) the regional sub-group owns a significantly higher number of books per student and has a much higher ratio of actual number to recommended, compared to the non-regional sub-group which belongs to the same type. Thus, the combined regional libraries' mean is $47.4 \mathrm{vs}$. only 13.5 in the combined ones located in towns or local councils; the regional combined branches' mean is 34.3 vs, only 1.7 (!) in the town/local ones; and the regional control group's mean is 17.7 vs. only 10.4 in the non-regional libraries of the control group. The same is true concerning the ratios of actual number of books to the recommended one: 4.74 vs. 1.35 for the main combined, 3.43 vs. 0.17 for the combined branches and 1.77 vs. 1.04 for the control group.

One may also see that the combined main libraries in towns and local councils, not to mention their combined branches, have a lower mean (and a lower ratio) than the regional libraries in the control group, which are uncombined. It is another indication that the greater resources of some combined libraries in the sample are probably a result of two factors: their affiliation with regional councils, and their being a combined library. The combined main libraries and branches had means of 47.4 and 34.3 , while the mean for the control group, though regional, is only 17.7.

Regarding acquisition of new books, the combined libraries group annually acquired more than double the control group, 1330 vs. 631, and again the regional (in the combined group) had a much higher mean than the urban one, 1414 vs, 1155 . Likewise, the average number of computers per library in the regional sub-group was over six, vs. three in the control group and less than two in the urban combined ones. 
The figures regarding librarian education do not support the assumption that one of the positive results of combining both types of libraries is upgrading the professional qualifications of the staff. A comparison of figures for the three types of libraries sampled shows a similar level of academic education as well as professional education in librarianship.

Concerning opening hours the urban combined libraries were open longer than the regional combined ones ( 46 vs. 44 hours per week) while the control group was open only 41 hours. The combined libraries, mainly the urban ones, were open more afternoon hours (50\% more than the control group) and all of them were open during school vacations, vs. $86 \%$ of the control group. The combined libraries had also a higher average number of weekly librarian hours per school compared to the control group, 78 vs. 62 hours, but 30 to 40 percent of these were spent on internal tasks, rather than on direct service to the students.

Library use and activity: the mean number of users of the reading-room was about the same (usually low) in all types of libraries in afternoon hours, but differed considerably in the mornings: 170 students daily in the regional sub-group vs. only 90 in the other two groups. The difference can probably be explained by the different teaching methods in the former group, which emphasizes personal projects, individual work, independent learning and self-directed homework rather than exams and frontal teaching. Activities of library instruction and reading encouragement were found in most regional and control-group libraries, but only in a few urban combined ones.

It is noteworthy that only 4 of the 18 combined main libraries (22\%) reported serving both the school population and the entire community, like a regular public library, as expected from a combined library. The remaining 14 libraries (78\%) served mainly the high school population, rather than the general community. Among the 11 combined branches, 7 libraries $(63 \%)$ served the high school community as well as adults of the general community, but not elementary school students. Only two branches reported serving all sectors in the community, from first grade to adults. Thus, it seems that, being affected by their location on school grounds, the combined libraries function mainly as school libraries and their staff are preoccupied with school and student needs, at the expense of general community needs. These findings corroborate former ones by White (1963), Unger (1977) and Nilsen (1992).

Overall evaluation: around $45 \%$ of the librarians in the combined libraries rated their combined library as 'very successful', while $22 \%$ rated it as only 'partially successful', and the rest $(33 \%)$ expressed dissatisfaction or pointed out serious problems. However, there was a considerable gap between regional and urban librarians: while $70 \%$ of the former group claimed that the model operated with 'great success', adding that they would recommend it, the opposite was true for the latter ones of whom only $12 \%$ gave a similar rating. A similar distribution was revealed among the school principals studied as well as among their teachers, although a considerable proportion of them declined to answer many of the questions related to the school library and their share in its routine functioning. There were some indications that principals of regular school libraries were more involved with the library activity than their colleagues in the combined ones. 


\section{Conclusions}

1. The combined model at the high school level in Israel has succeeded mainly in regional libraries serving the rural sector, and less in urban libraries and those belonging to local councils. In most parameters regional combined libraries rated high above other libraries studied: professional management, large collections, space, and opening time, especially on school vacations.

2. The combined model in urban settings was less successful, has faced various difficulties and rated worse concerning common parameters of input.

3. There are indications that the larger resources owned by the combined regional libraries are not being used to their full potential.

4. The relatively high proportion of librarians and principals who avoided rating their combined model as 'very successful' calls for further and more detailed investigation of the reasons to this finding.

\section{References}

Aaron, S.L. (1993). The role of combined libraries in Florida: phase I: surveying the literature. School library Media Annual, 7,31-120.

Aaron, S.L. and Smith, S.O. (1977). A study of the combined school public library: Phase 1. Tallahassee: State Library of Florida

Amey, L.J. (ed.). (1987). Combined libraries: The Canadian and Australian experience. Metuchen, NJ and London: Dalhousie University.

Haycock, K. (1973). The school media center and the public library: combination or cooperation. Toronto: Ontario Library Association

Haycock, K. (1990). The school-housed public library. Emergency Librarian 17, 34.

Nilsen, S. (1992). School libraries in Norway: encouraging independent learning. Scandinavian Public Library Quarterly 1, 15-17.

Unger, C. (1977). The school-housed public library revisited. MA Thesis, University of Chicago

White, R (1963). The schoothoused public library-a survey. Chicago: ALA. (Public Library Reporter, no. 11).

Woolard, W.L.B. (1980). Combined school/public ibraries: a survey with conclusions and recommendations. Metuchen, NI \& London: Scarecrow Press. 